\title{
Study of Low-Salinity Waterflooding For Sandstone Reservoir
}

\author{
Dwiky Pobri Cesarian 1 \\ ${ }^{1}$ S School of Physics, Universiti Sains Malaysia 11800, Pulau Penang, Malaysia \\ Coressponding Author. E-mail: \\ 1 dwikycesarian@student.usm.my
}

Received: 10 November 2018

Accepted: 1 Januari 2018

Online Published: 29 Januari 2019

\begin{abstract}
Recent studies showed that salinity concentration of the injected water is more important factor rather than the amount of water injected. The objectives of this study are to analyse the effect of salinity and its behaviour in waterflooding and calculating the recovery factor of the oil produced in sandtone reservoir condition. This study focuses on analysing the effect of salinity to its recovery factor, relative permeability, breakthrough time and water cut of the oil-water system. Laboratory experiment had been carried out to determine the recovery factor by using sandstone core with the dimension length and diameter of 3 in and $1.5 \mathrm{in}$, respectively. Sodium Chloride $(\mathrm{NaCl}$ ) was used to control the salinity concentration in waterflooding with range of 1,000 ppm to 14,000 ppm. The experiment was run with constant flow rate, pressure and temperature. In this experiment, deionized water with varied salinity and paraffin oil were used to perform the waterflooding procedure. Based on the results obtained, the highest total oil recovery by waterflooding was $57.8 \%$ with 4,000 ppm as the optimum salinity, which is $14.6 \%$ bigher than oil recovered by 14,000 ppm. The results also showed the change in end-point value of relative permeability. It also showed that water cut tend to increase as the salinity increase, while breakthrough time tend to decrease as the salinity increase.
\end{abstract}

Keywords: Waterflooding; Low-Salinity; Oil Recovery.

\section{Studi Injeksi Air Salinitas Rendah Pada Reservoar Batuan Pasir}

\begin{abstract}
Abstrak
Studi terbaru menunjukkan bahwa konsentrasi salinitas air yang disuntikkan adalah faktor yang lebih penting daripada jumlah air yang disuntikkan. Tujuan dari studi ini adalah untuk menganalisis pengaruh salinitas dan perilakunya dalam waterflooding dan menghitung faktor pemulihan minyak yang dihasilkan dalam kondisi batu pasir reservoir. studi ini berfokus pada analisis pengaruh salinitas terhadap faktor pemulihannya, permeabilitas relatif, waktu terobosan dan potongan air dari sistem minyak-air. Eksperimen laboratorium telah dilakukan untuk menentukan faktor pemulihan dengan menggunakan inti batupasir dengan panjang dimensi 3 in dan diameter 1,5 in. Natrium Klorida $(\mathrm{NaCl})$ digunakan untuk mengontrol konsentrasi salinitas dalam waterflooding dengan kisaran 1.000 ppm hingga 14.000 ppm. Eksperimen dilakukan dengan laju aliran, tekanan dan suhu yang konstan. Dalam eksperimen ini, air terdeionisasi dengan salinitas bervariasi dan minyak parafin digunakan untuk melakukan prosedur waterflooding. Berdasarkan hasil yang diperoleh, total perolehan minyak tertinggi dengan waterflooding adalah 57,8\% dengan 4.000 ppm sebagai salinitas optimal, yang mana 14,6\% lebih tinggi daripada minyak yang dipulihkan oleh 14.000 ppm. Hasil juga menunjukkan perubahan nilai titik akhir permeabilitas relatif. Eksperimen ini juga menunjukkan bahwa potongan air cenderung meningkat dengan meningkatnya salinitas, sementara waktu terobosan cenderung menurun dengan meningkatnya salinitas.
\end{abstract}

Kata Kunci: Injeksi Air; Salinitas Rendah; Pemulihan Minyak. 


\section{INTRODUCTION}

All of the oil that were created by the source rock in the reservoir is useless if it it's not being stored in a rock that has the ability to contain oil. A reservoir rock function as an underground storage where the oil migrates and held underground. There are two kinds of reservoir rock; commonly known there are the sandstones and carbonates. Both of these rocks have the ability to contain oil inside them, just like a pile of rock that were put together and has a room or "pore spaces" between them that can contain fluids.

Approximately $60 \%$ of all petroleum reservoirs are sandstones; outside the Middle East, carbonate reservoirs are less common and the percentage is even higher. The most important reservoir properties are porosity and permeability, but pore geometry and wetting properties of the mineral surfaces may also influence petroleum production. Sandstones provide reservoirs for oil and gas, but also for groundwater which is a fluid that is becoming increasingly valuable (Bjørlykke \& Jahren, 2010).

In an oil reservoir, the production of oil was produced in three stages, namely primary recovery, secondary recovery and tertiary recovery or enhanced oil recovery (EOR). Initially at the primary recovery stage, oil is produced by the reservoir's natural energy (fluid and rock expansion, solution-gas drive, gravity drainage, and aquifer influx). As the fluid was produced and the reservoir pressure were depleted, there is not enough natural energy to produce oil from the reservoir and the production rate will decrease. One of the ways to solve this problem is by performing secondary recovery, which can be done through various methods. At the final stage of the oil production, various Enhance Oil Recovery (EOR) procedures can be performed in order to increase the production rate.

At the first stage of production, only 10$30 \%$ of the oil originally in place (OOIP) is recovered and at the second stage, only 30-50\% of the OOIP is recovered (Castor, Somerton, \& Kelly, 1981). Waterflooding can increase that percentage known as the recovery factor and maintained the production at the optimum level for longer period. Normally secondary recovery started when the reservoir starts to decline and reduce production rate. Waterflooding was first practiced for maintenance after primary depletion and has since become the most widely adopted improved-oil-recovery (IOR) technique (Morrow \& Buckley, 2011).

Water injection or also known as waterflooding is one of the oldest and most common method that is used to maintain the reservoir pressure and increase the production rate. Basically, waterflooding performed by injecting water into the reservoir when the pressure has depleted over time to increase the pressure and stimulate production. The success of waterflooding method is determined by several factors such as oil properties, rock properties and characteristics, and composition and quality of the water that being used. All kind of water can be used in order to perform waterflooding, from produced water, seawater, aquifer water and river water. Produced water and seawater were often used since the source can be easily found.

In the early days, the amount of the water injected was considered as the most important factor in waterflooding. However, recently, many studies proved that the composition of water is the most important factor in increasing the recovery factor. Low-salinity waterflooding or known as LSW proven to be the best way to improve recovery factor.

Fluid and rock properties. The porous medium used in all experiments was a cylindrical core sample of sandstone rock with a length of $7.3 \mathrm{~cm}$ and $3.8 \mathrm{~cm}$ in diameter. The porosity was $16.0 \%$, and the permeability was $450 \mathrm{mD}$. Table 1 provides an overview of core sample properties. Brine with vary salinity of Sodium Chloride was used and paraffin oil used as crude oil in this experiment. The viscosity of the paraffin oil was $2.3 \mathrm{cp}$.

Table 1. Core Properties

\begin{tabular}{ll}
\hline Rock material & Sandstone Rock \\
\hline Diameter of the core & $3.8 \mathrm{~cm}$ \\
\hline Length of the core & $7.3 \mathrm{~cm}$ \\
\hline Porosity & $16.0 \%$ \\
\hline Permeability & $450 \mathrm{mD}$ \\
\hline
\end{tabular}

\section{METHODS}

A flow diagram of the overall experimental equipment is given in Figure 1. The core was put into a tri-axial core holder for the flooding processes. Firstly, the core was 100\% saturated with the brine before injected with the paraffin 
oil to have initial oil saturation. Then, waterflooding process followed. Brine was used during waterflooding process at constant injection pressure. The inlet pressure was kept constant at 10 psi with confined pressure inside the core holder was 150 psi. The process stopped after the water cut reach $90 \%$. The produced oil was measured. Water also produced during the flooding processes. However, since the paraffin oil was dye with red color, it was easier to measure the amount of oil produced

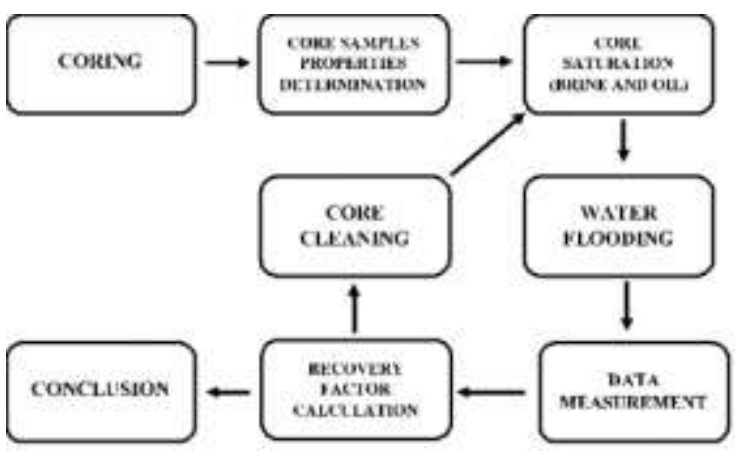

Figure 1. : Experimental flow diagram

\section{RESULTS AND DISCUSSION}

\section{Oil Recovery}

Figure 2(a) shows the oil recovery after waterflooding with four different brine salinities. The brines used were 2,000 ppm, 4,000 ppm, $8,000 \mathrm{ppm}$ and 14,000 ppm. The highest oil recovered was achieved by 4,000 ppm brine with $57.79 \%$ while the lowest oil recovered achieved by 14,000 brine with $43.51 \%$. The increase percentage in recovery with reduced salinity show the improvements in recovery resulting from the LSE. Although, the lowest salinity carried out in the experiment was at 2,000 ppm, the oil recovered was not the highest which is $50.15 \%$. Figure 2 (b) shows the oil recovered by waterflooding with the amount of water injected. The injected water was approximately at $6 \mathrm{PV}$ until the water cut reach about $90 \%$ before the process stopped. In the early waterflooding process, injection with 2,000 ppm brine showed the most highest oil recovered with only $0.4 \mathrm{PV}$ with $44 \%$ oil recovered.


Figure 2. (a). Oil recovery by waterflooding, (b). Oil recovery by the amount of water injected

\section{Relative Permeability}

Figure 3 shows the relative permeability end-point value of the waterflooding process. Based on previous study, the change in relative permeability could bring change to wettability state of the system. In Figure 4.3, it can be seen that the increment of the end-point value of the relative permeability to its optimum salinity was at column number 2 (4,000 ppm). This increment indicated that there is a possible change in wettability state of oil-water system towards more water-wetness. Nonetheless, wettability was out of the scope of this study. For example, if the initial wettability of the oil-water system was mixed-wet, the change would be towards waterwet state.

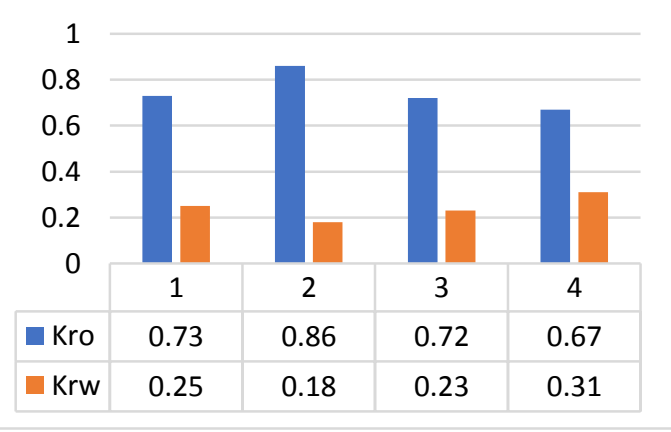

Figure 3. Relative permeability end-point value of the waterflooding 


\section{Breakthrough Time and Water Cut}

Table 2 shows the breakthrough time and water cut performance of different salinities. The longest breakthrough time was documented by 2,000 ppm brine with 559 seconds while the fastest breakthrough time was measured by 14,000 ppm brine with 266 seconds. From the experiment, it can be seen that breakthrough time decrease as the salinity increased. The watercut percentage was recorded after 1 hour of injection. The highest watercut percentage was at 14,000 ppm brine with $89 \%$ of watercut while the lowest was $2,000 \mathrm{ppm}$ brine with $83 \%$ of watercut. Here, it can be conclude that watercut tended to increase as the salinity increased, where the water produce were higher.

Table 2. Breakthrough time and water cut performance by waterflooding

\begin{tabular}{ccc}
\hline $\begin{array}{c}\text { Salinity } \\
\text { concentration } \\
\text { (ppm) }\end{array}$ & $\begin{array}{c}\text { Breakthrough } \\
\text { time } \\
\text { (seconds) }\end{array}$ & $\begin{array}{c}\text { \% water cut } \\
\text { (after 1 hour) }\end{array}$ \\
\hline 2,000 & 559 & 83.15 \\
4,000 & 575 & 83.35 \\
8,000 & 421 & 85.28 \\
14,000 & 266 & 89.38 \\
\hline
\end{tabular}

\section{Effect Of Salinity on Waterflooding}

Salinity was used as the variable in this experiment. From the results obtained, it clearly showed that salinity influenced the oil production process and its performance. Four different salinity rations were selected to be used in this experiment which were $2,000 \mathrm{ppm}, 4,000 \mathrm{ppm}$, 8,000 ppm and 14,000 ppm.

Generally, the recovered oil increased as the salinity of the water decreased. From those four salinities, 4,000 $\mathrm{ppm}$ produced the most recovered oil with $57.79 \%$, which $14.6 \%$ higher compared to $14,000 \mathrm{ppm}$. Although, 2,000 ppm was the lowest salinity used in the experiment, the oil recovered was not the highest.

Several factors were believed to be the reason that leadto this circumstance. First reason was the breakthrough time of waterflooding. Early water breakthrough may cause poor oil recovery. Once the breakthrough started, the injected fluid or in this case brine will bypass the oil and less oil will be recovered. Previous study concluded that, optimal performance occured when the EOR oil bank was produced just before the waterflood front reaches the producer (Gary R. Jerauld, 2000). Second reason was the effect of salinity to relative permeability in oil-water system. Based on previous study, the change in relative permeability could bring alteration to wettability state of the system. In Figure 4.3, it can be seen that the increment of the end-point value of the relative permeability to its optimum salinity was at column number $2(4,000 \mathrm{ppm})$. This increment indicated that there was a possible change in wettability state of oil-water system towards more water-wetness. The increment in relative permeability plots indicated the development of the oil-water system to more water-wet state. Improved oil recovery were generally supported by an increase in water wetness (Shaddel, Tabatabae-Nejad, \& Fathi, 2014). The more water-wet of the system, the more of oil can be produced. Therefore, low salinity benefit as a shift in wettability towards more water-wet state. Another reason is due to the reaction between the injected fluid and the minerals of the rock, the dissolution of the mineral may happened. The dissolution process caused the clogging in the pore spaces during the migration of the fines particles resulting from the chemical reactions that may trapped the oil.

\section{CONCLUSION}

The results of this study proved that salinity is critical and play important role to improve oil recovery in secondary recovery method. The experiment showed the optimum salinity for waterflooding was 4,000 ppm, which recovered oil as much as $57.79 \%, 14.63 \%$ higher than $14,000 \mathrm{ppm}$. Water cut tend to increase as the salinity increase, while breakthrough time tend to decrease as the salinity increase. Finally, the experiment proved that there is a change in end-point values of relative permeability with the changes in salinity.

\section{REFERENCES}

Bjørlykke, K., \& Jahren, J. (2010). Sandstones and sandstone reservoirs Petroleum Geoscience (pp. 113-140): Springer.

Castor, T., Somerton, W., \& Kelly, J. (1981). Recovery mechanisms of alkaline flooding Surface phenomena in enhanced oil recovery (pp. 249-291): Springer.

Morrow, N., \& Buckley, J. (2011). Improved oil recovery by low-salinity waterflooding. Journal of Petroleum Technology, 63(05), 106-112. 
Mohd Saiful Shaari Bin Mohammad. Study of gas flooding for carbonate reservoir. B.Eng Thesis. Universiti Teknologi Malaysia; 2013.

Bartlesville Energy Technology Center, U.S. Department of Energy, 1994

World Oil (editorial), "Practical Waterflooding Shortcuts", December 1966.

Abdallah, W., Buckley, J. S., Carnegie, A., Edwards, J., Herold, B., Fordham, E., Signer, C. (1986). Fundamentals of wettability. Technology, 38, 1125-1144.

Puntervold, T. (2008). Waterflooding of carbonate reservoirs: EOR by wettability alteration.

Romero-Zerón, L. (2012). Advances in Enhanced Oil Recovery Processes. University of New Brunswick, Chemical Engineering Department. Canada.

Wei, S., Shi, J., Gu, J., Wang, D., \& Zhang, Y. (2012). Dynamic wettability of wood surface modified by acidic dyestuff and fixing agent. Applied Surface Science, 258(6), 1995-1999.
Anderson, W. G. (1987). Wettability literature survey-part 6: the effects of wettability on waterflooding. Journal of Petroleum Technology, 39(12), 1,605-601,622.

Shaddel, S., Tabatabae-Nejad, S. A., \& Fathi, S. J. (2014). Low-salinity waterflooding: evaluating the effect of salinity on oil and water relative permeability, wettability, and oil recovery. Special Topics \& Reviews in Porous Media: An International Journal, $5(2)$.

Zeinijahromi, A., Lemon, P., \& Bedrikovetsky, P. (2011). Effects of induced fines migration on water cut during waterflooding. Journal of Petroleum Science and Engineering, 78(3), 609-617.

Isehunwa, S., \& Olubukola, O. (2012). Interfacial Tension of Crude oil brine systems in the Niger Delta. Inter J Res Rev App Sci, 10, 460-465.

Gary R. Jerauld (2000), “Timing of Miscible Hydrocarbon Gas Injection after Waterflooding". Presented at the 2000 SPE/DOE Improved Oil Recovery Symposium held in Tulsa, Oklahoma. SPE 59341. 